\section{Review on Main Characteristic of Historical City as an Urban Design Alternative: A case study in Cakranegara City, Indonesia}

\author{
Lalu Mulyadi ${ }^{*}$ \\ 1 Department of Achitecture, Faculty of Civil Engineering and Planning, National Institute of \\ Technology (ITN) \\ * Corresponding Author,Email:lalu_mulyadi@yahoo.com \\ Received 12 September, 2013; Accepted 5 May 2014
}

Key words: $\quad$ Main Characteristic, Urban Design, Cakranegara City

\begin{abstract}
The main problem of conserving old Indonesian cities is how their changes are still accepted without eliminating their main characteristics. Cakranegara is one of the old cities in which its main characteristic should be known. The griddesigned pattern of Cakranegara is an architecturally beautiful Hindu Balinese pattern with its own unique identity. The study of the main characteristic of Cakranegara was done by matching the basic principle of the social culture and religious beliefs with the empirical field data. The research adopted four methods: questionnaire, cognitive mapping, interview, and visual observations. The data of the questionnaires was analyzed by descriptive statistics, while the data of the cognitive mapping, interviews, and visual observations were analyzed qualitatively. The next was then the assessment of the design of settlement blocks, the crossroads, the urban design, the spatial orientation and hierarchy by triangulation process. Thus, the basic principle of the social culture and the religion results in the realization of the main characteristic of the historical city of Cakranegara.
\end{abstract}

\section{INTRODUCTION}

Urban design existing in Indonesia nowadays is still focused on the same forms; as a result, no more attention is given to urban design based on the variety of the social cultures. An example of this is the administrative boundaries among districts as units of the urban designs of which the sociocultural aspects are then neglected (Samadhi, 2004).

Wiryomartono (1995) and Samadhi (2004) state that there are urban areas like Nagari in Padang, Gampong in Aceh, and Desa Adat in Bali having valuable social cultures, which have a close relationship with the realization of the area's values. Therefore, the building and development of historical cities should consider the character of their valuable social and cultural aspects. Hermanislamet (1999) states that research should be conducted towards the old historical Indonesian cities and social cultures of high values because they provide theoretical concepts as references to build urban areas.

Cakranegara, one of the old Indonesian historical cities in Lombok-East Indonesia, has a spatial specification and unique social cultures. According to Funo (1995), Cakranegara is a city having a grid pattern which is built in the form of settlement blocks called Karang. Handinoto (2000) says that Cakranegara is one sample of old cities which is designed based on
This open access article is published under a Creative Commons [AttributionNonCommercial-NoDerivatives 4.0 International] license.

https://creativecommons.org/licenses/by-nc-nd/4.0/ 
cosmology and has morphology as well as a specific social culture. The question is, then, how can the basic principle of the social culture and the religion provide the main characteristic of the historical city of Cakranegara?

\section{CONTRIBUTION}

The purpose of this study is to provide a new architectural and urban design theory, especially dealing with the spatial theory. It will be useful for the local government as a reference for planning and formulating the conservation of Cakranegara city. For Indonesian urban designers, the theory will become an inspiration to develop existing cities and an international reference for grids from Indonesia. For future researchers, the analysis frame of the study can be one of the alternative models for the same kind of studies either in Indonesia or in other countries.

\section{THE HISTORY OF CAKRANEGARA CITY}

Cakranegara was founded historically in a long process in Bali from the beginning of the existence of the Gel-Gel kingdoms. In the 15th century, the Gel-Gel regime colonized Lombok, Sumbawa, and Blambangan (East Java) reigned by Dalem Watu Renggong. After his death, his reign was moved to Karangasem at the northern part of the Gel-Gel kingdoms. The height of his glory ended after the fourth king of Karangasem. One of his princes, I Gusti Anglurah Ketut Karangasem, enlarged his colony to Lombok (Cakranegara) around 1692. De Graaf (1941) thought that the ruin of Gel-Gel coincided with the colony of Karangasem to the island of Lombok. The conquer of Karangasem Bali over Lombok was due to the unpleasant political situation between two powerful kingdoms in Lombok, Selaparang in East Lombok and Pejanggik in Central Lombok.

Kings Karangasem took this opportunity to conquer the island of Lombok and to found the small kingdoms in west Lombok like: Kediri, Sengkongo, Pagutan, Pagesangan, Mataram and Singasari. After Lombok was conquered from 1692 to 1740 , at the site that was called Singasari, now called Cakranegara meaning a settlement city in a rounded shape; Cakra means 'circle' in Sanskrit and negara means city, settlement, or country (Agung, 1992).

\section{THEORETICAL BACKGROUND}

\subsection{The Basic Principles of the Social and Religious Cultures of the Balinese Hinduism}

\subsubsection{The principle of Asta Dikpalaka}

Munandar (2005) states that Hindu civilization in the names of the gods who occupy the throne on the eight directions of the compass are called Asta Dikpalaka. Asta Dikpalaka, who in myth are said to surround Mount Mahameru. From Mount Mahameru its aspects are: the north - dewa Kumera, the northeast - dewa Isana/Candra, the east - dewa Indra, the southeast dewa Agni, the south - dewa Yama, the southwest - dewa Nirtti/Surya, the west - dewa Waruma, and the northwest - dewa Wayu. 
The eight gods of Asta Dikpalaka are worshiped as dewa Kuwera who is the god of prosperity who guards the north of the compass, dewa Isana is the other name of dewa Syiwa who guards the northeast of the compass, Isana or dewa Syiwa who is the god of mortality who is the highest god in Trimurti, dewa Indra who was worshiped as the god of war in the Weda era and is considered as the king of the gods who guards the east compass, dewa Agni who is worshiped as the god of fire who guards the southeast compass, dewa Yama who is the god of mortality who guards the south compass and, dewa Surya who is the god of the sun. The position of dewa Surya in the southwest compass is reflected by dewa Nirtti (the god of grief). When the corner of the southwest is guarded by dewa Surya, the corner of the northeast is guarded by Chandra (Soma); but when the southwest is guarded by dewa Nirtti, the northeast is guarded by Isana. Dewa Waruna who is worshiped as the god of the sea who guards the west, and dewa Wayu is worshiped as the god of the wind who guards the northwest of the compass.

\subsubsection{The principle of Rwa Bhinneda}

The universe is created in balance systematically. There is a basic principle to maintaining balance in the system, that is, the concept of being in couples. Aminuddin (1999) says that there would not be any meaningful life if there were just one species occupying the universe and dominating this cosmos. That is the reason God has created human beings and other creatures living in couples naturally. This concept makes the universe with its life perfect and beautiful. According to Aminuddin (1999), the first harmonious couple is a man and woman as spouses. The second couple is of the organs of a body in pairs like, the eyes, the feet, and the hands. The third thing is of life: rich-poor, righteousness-evil, and mortality-immortality. The fourth thing is of physical nature: the land-the sea, the highs-the lows, the rain-the hot, and the day-the night.

The couple system stated by Aminuddin (1999) has the same significance as binary opposition written by Levi-Strauss (1969) in Totemism. He defines the coupling of different sexes as a method to analyze the social phenomena whose way of thinking comes from the human classification of the environmental world. Levi-Strauss (1969) has the same opinion about classification based on different characteristics.

Hindu people in Bali, for example, think that the couple system in the universe is a consistent order of the cosmos. They are oriented in a balance and keep the harmonious relation between the universe as macro-cosmos and the human beings as micro-cosmos. This order is based on the philosophy of reconciliation of the two poles, of which the values are different, but tied in relation, either, among the objects, man with objects or man with other living things as well as man with his God (Rahardjo (1989); Budihardjo (1991)).

The philosophy of reconciliation has significance related to the social belief of Bali Hinduism to God, the Almighty (Pidarta (2000); Sudharta and Atmaja (2005)); Suwena (2003) says that the philosophy of reconciliation for the Balinese Hinduism is called the principle of Rwa Bhinneda. Rwa means two and Bhinneda means different. The principle of Rwa Bhinneda is reflected in the orientation order: the mountain-the sea, dirty-clean, luanteben, sekala-niskala, and sacred-profane (Parimin (1986); Gelebet (1986); Widana (2002)).

Parimin (1986), Mantra (1988), Budihardjo (1991), and Widana (2002) state that the implementation of Rwa Bhineda principles into spatial orientation is the sacred directioning of a mountain that is centered with an 
orientation of high value and genesis. On the other hand, things which are not sacred are directed to the sea. The sea comprises bad values and, therefore, it connotes dirty things. According to Parimin (1986), Gelebet (1986), Budihardjo (1991), Samadhi (2001), Geriya (2004), and Eiseman (2005), binary opposition is physically implemented in the spatial pattern of a city, village, settlement, or house yard. Ardi shows the Puseh temple and Desa temple are situated towards the mountain; whereas the Dalem temple (the temple related to mortality and graveyards) are situated towards the sea.

\subsubsection{The principle of Sekala - niskala}

Sekala is a visible object, whereas niskala is an invisible one. Both are supernatural. Balinese Hinduism thinks that the invisible objects belonging to the supernatural are realized as real objects in order that man is directly able to contact with them (Suparman (2003); Soeka (2004)). Furthermore, Suparman (2003) adds that the temple is a place for worship to God that is a sekala, that is, a reflection of niskala. Eiseman (2005) states that dances (sekala), which are acted out in Balinese Hinduism, are the symbols of invisible powers (niskala).

Suparman (2003) and Soeka (2004) state that the highest power in the universe is just God. The power of God is classified into three kinds: the power to create, to care for, and to return to Him. Basically, God is unseen and untouchable. Balinese Hinduism is anxious to be able to contact directly with God in God's real form (sekala). Therefore, they reflect God's character in the form of dewa (God). God creates dewa from the light and becomes his envoy (Puja (1985)). The purpose of transforming God to be real (sekala) is to make it easy to relate their thoughts to God.

According to the people of Balinese Hinduism, there are three kinds of dewa named after Tri Murti: dewa Brahma, dewa Wisnu, and dewa Syiwa. Dewa is immortal and has different tasks from other creatures. According to Suparman (2003) and Soeka (2004), the three dewas are uttered in one word, that is AUM. "A" means Agni (fire, the symbol of Brahma), "U" means Uddaka (water, the symbol of Wisnu), and "M" means Maruta (wind, the symbol of Syiwa). The tasks of the three dewas are: Dewa Brahma creates all creatures in the universe. He is given a throne in the form of sekala (Desa temple). Dewa Wisnu is the transformation of the power of God whose task is to maintain the universe with regard to human welfare, happiness, the life of animals, and plants; his throne is Puseh temple. Dewa Syiwa is the transformation of the power of God whose task is to return all the shapes to their origins. Dewa Syiwa has the power of life duration to end all the life of growth and creatures., he is given a throne in the form of sekala (Dalem temple).

\subsubsection{The principle of tri Hita Kharana}

Tri Hita Kharana comes from three words. Tri means three; Hita means righteousness; and Kharana means source, so the Tri Hita Kharana consists of the righteousness. Tri Hita Kharana has the teaching of philosophy about adaptable and harmonious living in all aspects of life. According to Monografi (1985), Kaler (1994), and Putra in Atmaja (2003), the three sources provide the relationship between human beings with their God, among the humans and the humans with their environment.

According to Gelebet (1986), the three elements of Tri Hita Kharana are atma, khaya, and angga (soul/spirit, energy, and physical/body). Dharmayudha and Cantika (1999) say that the Tri Hita Kharana are atman, 
prana, and sarira (Table 1). The three points as the source of life are soul/spirit, energy, and physical/body. Man with his life can take an important, high role in his life if his life is in balance. According to Patra (1992), Gorda (1996), Atmaja (1999), and Samadhi (2001), spatial patterns adopting the principle of Tri Hita Kharana can be seen in the form of Parahyangan, that is, the site of worship for the spirit. Pawongan is when the people living in an area are an energy, and Palemahan is the territorial form which functions physically.

Table 1. The Elements of Tri Hita Kharana

\begin{tabular}{llll}
\hline Tri Hita Kharana & $\begin{array}{l}\text { SOUL/SPIRIT } \\
\text { (atma) }\end{array}$ & $\begin{array}{l}\text { ENERGY } \\
\text { (prana) }\end{array}$ & $\begin{array}{l}\text { PHYSICAL/BODY } \\
\text { (sarira) }\end{array}$ \\
\hline Universe & Paraatman & $\begin{array}{l}\text { Power to move the } \\
\text { universe, e.g. planetary } \\
\text { movement }\end{array}$ & $\begin{array}{l}\text { Panca Maha Bhuta } \\
\text { elements }\end{array}$ \\
$\begin{array}{l}\text { City/village/desa } \\
\text { adat }\end{array}$ & $\begin{array}{l}\text { Tri Kahyangan or } \\
\text { Parahyangan }\end{array}$ & $\begin{array}{l}\text { Sima karma or } \\
\text { Pawongan } \text { or } \\
\text { dwellers/villagers and } \\
\text { their activities } \\
\text { House dwellers }\end{array}$ & $\begin{array}{l}\text { Palemahan or } \\
\text { settlement/village } \\
\text { territory }\end{array}$ \\
House & House temple & $\begin{array}{l}\text { Dwelling unit with its } \\
\text { yards } \\
\text { Physical/Body }\end{array}$ \\
Human being & Soul/spirit & Energy & and
\end{tabular}

(Source: Gelebet (1986); Dharmayudha and Cantika (1999); Patra (1992); Gorda (1996); Atmaja (1999); and Samadhi (2001))

\subsubsection{The principle of Tri Angga, Tri Mandala, Tri Loka}

Basic philosophical culture and religion are the source of the rules of Tri Angga, Tri Mandala, and Tri Loka. Tri Angga means three levels of values in an object; Tri Mandala means three levels of values in a space; and Tri Loka means three levels of values in the universe. All of these values are termed utama, madya, nista. When three levels of value are applied to the universe, they are the atmosphere (Shuahloka), the lithosphere (Bhuahloka), and the hydrosphere (Bhurloka). On Earth, they are mountain, continent, and sea. In cities, they are temples, settlement area, and graveyard. For human beings, they are head, body, and legs (Samadhi (2004)). When the terms utama, madya, nista are used in an area, there will be three spacious values called Tri Mandala. Tri means three; Mandala means square or space (Atmaja (2003)). When studied more deeply, the principle of Tri Mandala is the development of Rwa Bhinneda, that is, the existence of the east, the west and the mountains and the sea (Parimin (1986); Budihardjo (1991)). If two kinds of power are exposed, there will be a value in between called madya.

\section{METHODOLOGY}

The methodology adopted to describe the content of the article is based on the relevant study. According to Shuhana (1997), there are two main kinds of methodology in conducting a research about historical urban areas, qualitative and quantitative methodologies. Quantitative methodology uses the questionnaire method, whereas qualitative methodology is based on a field study. According to Festinger and Katz (1953), the difference of both methodologies is in the evaluation. The questionnaire method is broader whereas the field study method is more complete. The adoption of both methodologies will result in more accurate information.

Shuhana (1997) adds that the study of a historical urban area cannot be conducted just by adopting one certain methodology for its specific characteristics. Bell and Greene (1990) assert that an urban study should be 
conducted by various kinds of method, and then triangulated to find the more accurate result.

Both methodologies are the basic methods in this study of Cakranegara, the historical city. The use of the quantitative method involves the people's evaluation of the environment of the city (Salim (1992); Shuhana (1997)). Banerjee and Southworth (ed.) (1990) suggest the people's experience about an environment are very useful for the researcher because they know the real situation thoroughly. Therefore, the findings of the analyzed questionnaire can represent a large number of the population, enabling this method to be used as the fundamentals of a qualitative method.

\subsection{The Procedure of Data Collecting}

\subsubsection{Questionnaire technique}

The distribution of the questionnaire was done by simple random sampling distributed to the blocks of the homogeneous settlement dwellers. Sugiyono (2009) supports this method. There were 330 respondents taken as the sample with validity of $95 \%$ and correction $5.5 \%$. The number is based on the assumption and the validity by De Vaus (1991).

\subsubsection{Cognitive Mapping Technique}

Data collecting by cognitive mapping was carried out in the Cakranegara area involving 30 respondents. This was based on Shuhana (1997) and Shuhana and Ahmad (1999). The 30 respondents consisted of the dwellers being studied and were selected based on purposely sample.

They were interviewed about the elements they remembered dealing with in Cakranegara city. The elements are considered important because they have specific values, significant and outstanding, to be compared to the other elements.

\subsubsection{The Technique of Interview}

Data collecting by interview of the residents of Cakranegara uses a list of questions referring to the objective of the research. The respondents are classified based on their levels of education, values, norms, custom rules, and their implementation in life involving the leader of each social element.

There are 30 respondents as purposely sample. According to Walker (1985), 20 to 30 respondents are adequate to conduct qualitative and quantitative studies.

\subsubsection{The Visual Observation Technique}

In visual observation activities, the researcher is just an independent observer meaning that the observer is free to observe, examine and do the measure. According to Spreiregen (1965), a visual observation activity is very good to know the composition, the city shape and to evaluate the potentials and the shortcomings of a city. Shuhana and Ahmad (1992) say that the use of technical observation to conduct a research of a historical city area has advantages especially on the effectiveness to describe the city/town thoroughly. Shuhana and Ahmad (2002) add that the thorough evaluation of the physical character of a city can be obtained by a visual observation and recording of the physical elements of the city. The recording of the 
standardized physical city elements is important to know the design of the city.

\subsection{The Procedure of Data Analysis}

Empirical data were collected adopting four methods, namely questionnaire, cognitive mapping, interview, and visual observation, by the researcher. The questionnaire data is analyzed statistically, while cognitive mapping data, interview, and visual observation are analyzed qualitatively, then they will be triangulated. The findings of the triangulation analysis will be matched with the described theories according to the theoretical background, so that the main characteristic of the historical Cakranegara city will be discovered.

\section{THE RESULT AND THE DISCUSSION}

\subsection{The Settlement Blocks}

The respondents of the questionnaire from Cakranegara were 268 individuals, (81.2\%) Hindu, 50 (15.2\%) Muslim, 4 (1.2\%) Buddhist, and 8 (2.4\%) Christian.

According to Wacana (1988), Zakaria (1998), and Djelenga (2001), the blocks dwelt in by the Hindu community have been continuously existing since the seventeenth century (from the year 1692, to be precise), when the area was ruled by the Balinese Hindu kingdom of Karangasem.

The result of the observation of Cakranegara is 36 settlement blocks, which include 33 blocks dwelt in by the Hindu community in the center of the city, two blocks by the Muslim community on the southeast corner, and one block of vacant land on the southwest corner. The result of the interview with the local community found that the main sources of community income were entrepreneurship and civil servantry. The Muslim community, which inhabits the southeast corner block, comes from a long line of skin cracker producers.

The result of the observation on one block of settlement units was that they stretch in a north-south direction, and their gates face either to the east or to the west. Based on the measurement conducted by the researcher, each of the settlement units occupies a square area of, on average, $729 \mathrm{~m}^{2}$, or 27 meters on each side. The length of the road on each side of a block is 27 meters, and the length of each road that divides blocks into settlement units is 9 meters. According to Funo (1995) and the local community, the settlement unit in one block is divided in some levels. The smallest level, with 20 settlement units, are called marga. The medium level, with 40 settlement units, are called kriang, and the largest level, with 80 settlement units are called karang (Figure 1b). 


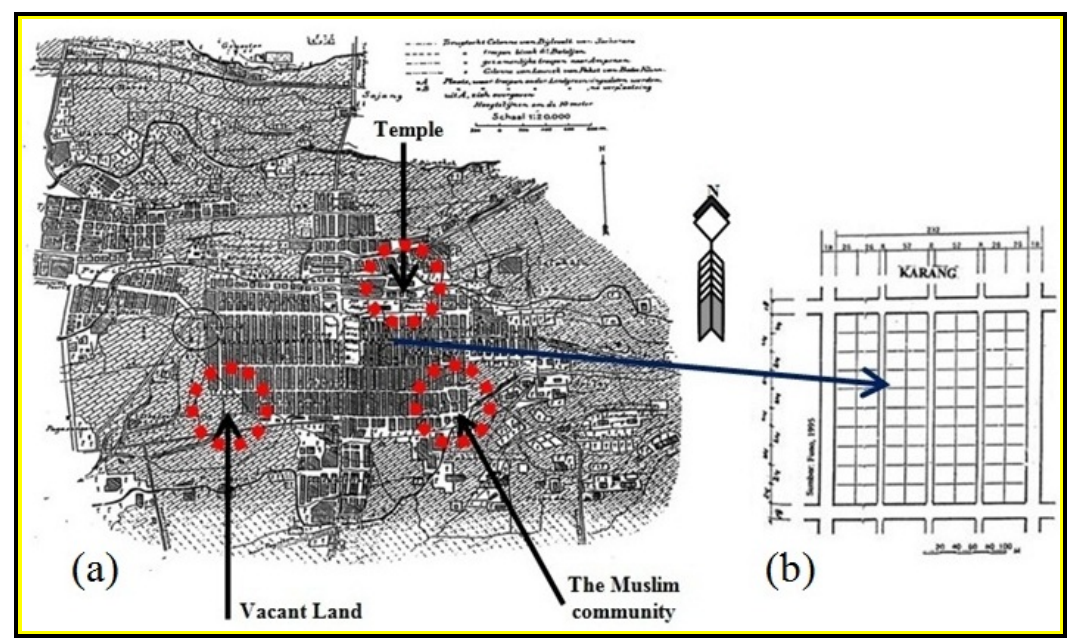

Figure 1. (a) Cakranegara City Map and (b) Settlement Blocks (Source: (a) Cool (1896); (b) Funo (1995))

The findings, when matched between the principal of Asta Dikpalaka, with the positions and functions of the settlement block in Cakranegara city, will surely show that the settlement blocks adopt the principal of Asta Dikpalaka. The empirical evidence is that, first, in the northeastern corner is the position of the worship block which is in accordance with the position of dewa Isana, which is the other name of dewa Syiwa. Second, at the southeast corner is the block of thte Muslim community whose profession is as skin cracker producers. This is in accordance with the position of dewa Agni (Agni is fire). Fire is the main utensil to fry skin cracker. Third, at the northwest corner is the position of the block of vacant land which is in accordance with dewa Nirtti. Nirtti is the god of grief; therefore constructing settlement buildings is not allowed (Figure 1a).

\subsection{The Crossroads}

The result of the questionnaire regarding the crossroads in Cakranegara city is that 238 respondents $(84.80 \%)$ out of 330 were able to explain that one of the characteristics of Cakranegara is the presence of a lot of crossroads, public temples, and settlement blocks (Table 2). The result of the cognitive mapping is that 28 respondents $(93.3 \%)$ out of 30 could draw crossroads very well and clearly (Table 3 ). The resulting interview with the local community was that 30 respondents $(100 \%)$ out of 30 revealed that Cakranegara has a lot of crossroads. Meanwhile, visual observation by the researcher registers two types of crossroads, that is, the crossroad located in the center of the city and crossroads located in settlement blocks. The crossroads at the center of the city, called pempatan agung, serve to accommodate city-wide and social-cultural activities and religious rituals. As for the crossroads located in settlement blocks, called pempatan madya, they function as the center of neighborhood-wide and social-cultural activities and religious rituals.

Prior to the processions of religious rituals, tawur agung in particular, offerings are arranged at the crossroad. According to Eiseman (2005), participants arrange the offerings as follows: black cloth and four sticks of sate (grilled chicken) are set in the north, offered to dewa Wisnu, to symbolize kaja or apah; red cloth and nine sticks of sate are set in the south, offered to dewa Brahma, to symbolize kelod or teja; white cloth and five sticks of sate are set in the east, offered to dewa Iswara, to symbolize kangin or bayu; yellow cloth and seven sticks of sate are offered to dewa 
Mahadewa, to symbolize kauh or pratiwi; and gray cloth and eight sticks of sate are set at the center, offered to dewa Syiwa, to symbolize puseh or akasa (Figure 2a). Interviews with religious leaders reveal that north is the region guarded by dewa Wisnu, south by dewa Brahma, east by dewa Iswara, west by dewa Mahadewa, and center dewa Syiwa.

\begin{tabular}{llllll}
\multicolumn{6}{c}{ Table 2. Respondents Perception of Physical Characteristics Cakranegara City } \\
\hline & & Frequency & Percent & $\begin{array}{l}\text { Valid } \\
\text { Percent }\end{array}$ & $\begin{array}{l}\text { Cumulative } \\
\text { Percent }\end{array}$ \\
\hline \multirow{4}{*}{ Valid } & 1 and 2 & 37 & 11.2 & 11.2 & 11.2 \\
& 1 and 3 & 5 & 1.5 & 1.5 & 12.7 \\
& 1,2 and 3 & 238 & 72.1 & 72.1 & 84.8 \\
& $1,2,3$ and 4 & 50 & 15.2 & 15.2 & 100.0 \\
& Total & 330 & 100.0 & 100.0 & \\
\hline Total & & 330 & 100.0 & &
\end{tabular}

(Source: Mulyadi, L. (2008))

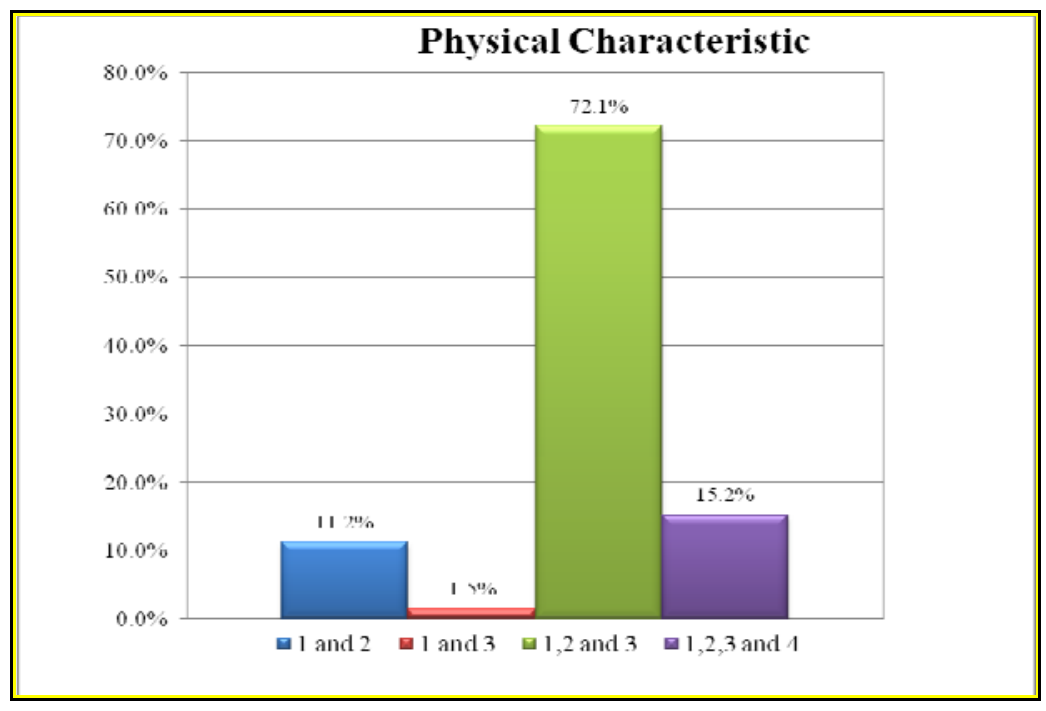

Legend:

1. Crossroads

2. Temples (Meru, Mayura, and Dalam)

3. Settlement Blocks

4. Others

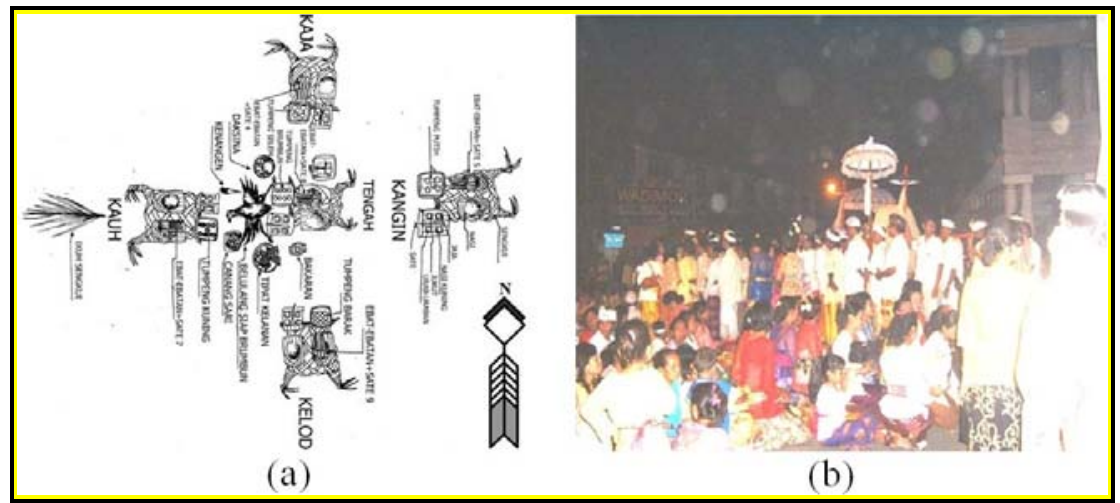

Figure 2. (a) Formation of Spatial Arrangement of Offerings at the Crossroad (b) The Ritual Conditions of Tawur Agung (Source: (a) Eiseman (2005); (b) Mulyadi (2008))

The findings, when the principle of Panca Brahma and the arrangement of the traditional feast are matched, and on certain crossroads, religious rituals are carried out (Figure 2b); so it will surely be found that crossroads 
in Cakranegara city adopt the principal of Panca Brahma. The empiric evidence is that, when the traditional feast is prepared for the gods before a religious ritual, it is held at a crossroad.

\subsection{The City Structures}

The result of the visual observation by the researcher reveals that in terms of width there are four types of road in Cakranegara. First, the EastWest roads (Selaparang and Pejanggik streets) are 45 meters wide. Second, the North-South roads (Sultan Hasanuddin and Anak Agung Gede Ngurah streets) are 36 meters wide. The North-South roads and East-West roads intersect as a crossroad that, according to Funo (1995), Handinoto (2000), and Mulyadi (2008), the local community calls Marga Sanga. Third, the roads that divide the settlement blocks into squares are 27 meters wide. These roads are called Marga Dasa. Fourth, the roads that divide the settlement blocks into rectangular sub-blocks are 9 meters wide. These roads are called Marga (Figure 4).

The result of the interview with the local community reveals that roads in this city serve to accommodate social-cultural activities and religious ceremonies, which include funeral ceremonies (Figure 3.b), and mendak tirtha (Figure 3.a), a ritual ceremony for the taking of sacred water.

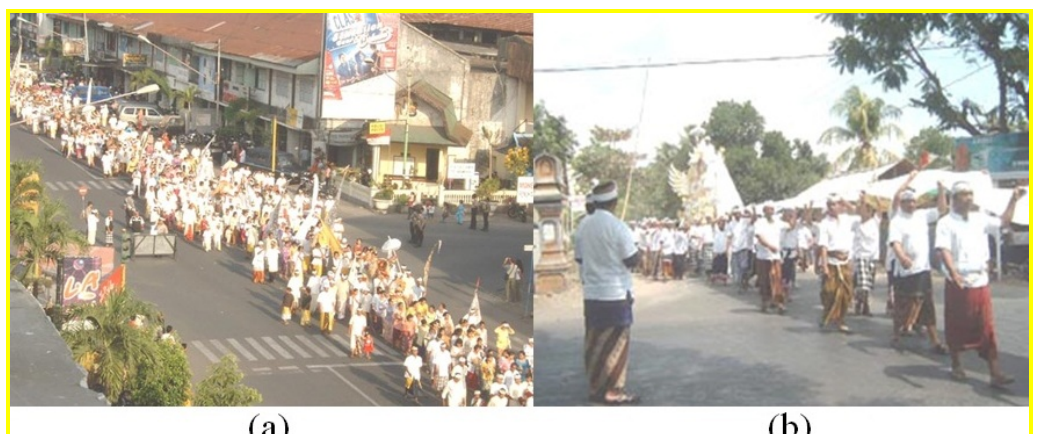

(a)

(b)

Figure 3. (a) The Mendak Tirtha Ceremony and (b) The Funeral Ceremony (Source: Mulyadi (2008))

The result of the cognitive mapping of Cakranegara is that 29 respondents (69.7\%) were able to sketch the cognitive maps of the 45 meterwide roads, 24 respondents $(80.0 \%)$ the 27 meter-wide roads, and 14 respondents (46.7\%) the 9 meter-wide roads (Table 3).

According to Funo (1995), the grid pattern is used because of the need to divide settlement blocks called Karang (Figure 1b). The result of the interview with the local community in general reveals that the formation of the grid pattern is related to the demand to hold social activities and religious ritual ceremonies. As for the interviews with religious leaders, they reveal that the formation of the grid pattern is inseparable from the presence of crossroads, which are necessary for the Hindu community in Cakranegara because the community believes that it is in the crossroads that the power to protect an area emerge. This is in accordance with the argument shared by Budihardjo (1991); Hermanislamet (1999); and Eiseman (2005), that the crossroads of Hindu cities in Indonesia are sacral spots.

The findings, when matched with the principles of Panca Brahma and city structures, show that there will be means by which the structure of Cakranegara city adopts a grid pattern (Figure 4). The information related to the grid pattern found,first, the importance of a place to accommodate the social and ritual religious activities, such as the yadnya ritual (Figures $3 a$ and $3 b$ ), second, that in 1692 the Masehi, the immigrants who came to Bali 
Island in groups from their native region, accommodated themselves in one block of settlement, and third, the belief of niskala power at each crossroad will provide the defense for the castle of Cakranegara city.

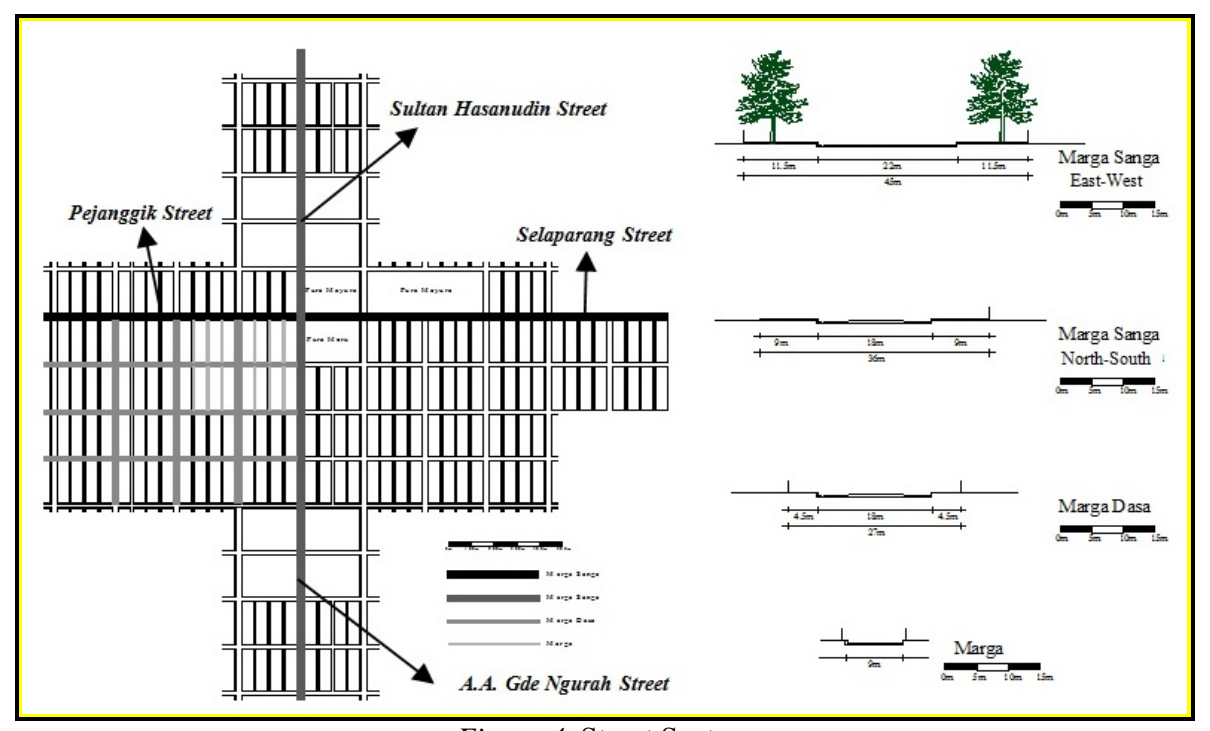

Figure 4. Street System

(Source: Mulyadi (2008))

Table 3. Elements of the Sketches Respondents

\begin{tabular}{lllll}
\multicolumn{2}{l}{ Sketch of elements } & Frequency & $\begin{array}{l}\text { Responden } \\
\text { Total }\end{array}$ & $\begin{array}{l}\text { Valid } \\
\text { Percent }\end{array}$ \\
\hline \multirow{6}{*}{ Meru temple } & $\mathbf{3 0}$ & $\mathbf{3 0}$ & $\mathbf{1 0 0 . 0}$ \\
& Mayura temple & $\mathbf{3 0}$ & $\mathbf{3 0}$ & $\mathbf{1 0 0 . 0}$ \\
& Dalem temple & $\mathbf{2 8}$ & $\mathbf{3 0}$ & $\mathbf{9 3 . 3}$ \\
Building & Melanting temple & $\mathbf{9}$ & $\mathbf{3 0}$ & $\mathbf{3 0 . 0}$ \\
& Market of Cakranegara & $\mathbf{2 8}$ & $\mathbf{3 0}$ & $\mathbf{9 3 . 3}$ \\
& Market of Sindu & 7 & $\mathbf{3 0}$ & $\mathbf{2 3 . 3}$ \\
& Mataram Mall & $\mathbf{2 8}$ & $\mathbf{3 0}$ & $\mathbf{9 3 . 3}$ \\
& MGM Mall & $\mathbf{2 7}$ & $\mathbf{3 0}$ & $\mathbf{9 0 . 0}$ \\
& Mosque & $\mathbf{6}$ & $\mathbf{3 0}$ & $\mathbf{2 0 . 0}$ \\
Street & Crossroads & 28 & 30 & 93.3 \\
& 45 m street & $\mathbf{2 9}$ & $\mathbf{3 0}$ & $\mathbf{9 6 . 7}$ \\
& 27 m street & $\mathbf{2 4}$ & $\mathbf{3 0}$ & $\mathbf{8 0 . 0}$ \\
& 09 m street & $\mathbf{1 4}$ & $\mathbf{3 0}$ & $\mathbf{4 6 . 7}$ \\
Landscape & Mayura garden & $\mathbf{3 0}$ & $\mathbf{3 0}$ & $\mathbf{1 0 0 . 0}$ \\
& Vacant land & $\mathbf{1 6}$ & $\mathbf{3 0}$ & $\mathbf{5 3 . 3}$ \\
District & District territorial & $\mathbf{2 3}$ & $\mathbf{3 0}$ & $\mathbf{7 6 . 7}$ \\
\hline Settlement blocks & $\mathbf{2 5}$ & $\mathbf{3 0}$ & $\mathbf{8 3 . 3}$ \\
\hline
\end{tabular}

(Source: Mulyadi (2008))

\subsection{The Spatial Orientation and Hierarchy}

According to Parimin (1986), Sularto (1987), and Soewarno (1990), to know the orientation and spatial hierarchies of Balinese traditional villages, a researcher should do a visual observation by checking the position of three temples (Kahyangan Tiga) where the inhabitants of a particular area practice their worship ritual, checking the settlement pattern of the community, and checking the territory. Meanwhile, Suwena (2003) argues that each Balinese traditional village has its own orientation and hierarchy. A researcher can find them by observing the land use and topography of the region to determine whether it is an elevated, plain, or low-lying area.

Furthermore, Parimin (1986), Sularto (1987), and Soewarno (1990) state that the orientation and hierarchy of city or traditional village area in Bali can be seen from the presence of two temples (Desa and Puseh) in the 
northernmost part of the city, a temple (Dalem) and a graveyard in the southernmost part, and these residential area in between these two groups. Meanwhile, Parisada Hindu Dharma (1995) argues that the two temples that are in the northernmost part are high value because they directly face towards the mountain, and the one temple on the southernmost part is not really good because it faces towards the sea.

According to Samadhi (2004), city areas in Bali have the following spatial hierarchies: three temples called Parahyangan, the territorial border called Palemahan, and the dwelling community called Pawongan.

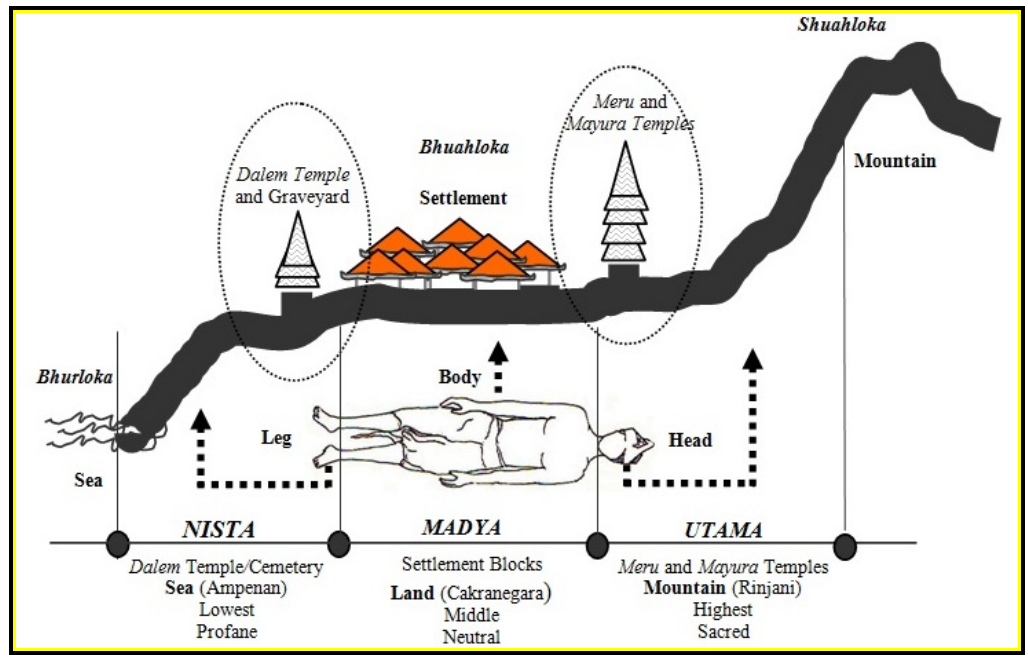

Figure 5. The Elemens of Tri Angga; Tri Mandala; and Tri Loka

(Source: Mulyadi (2008))

The result of the interviews, cognitive mapping, and the visual observation by the researcher conducted in Cakranegara city has found the presence of two temples of worship (Meru and Mayura) to the east from the central crossroad and one temple (Dalem) in the westernmost part of the city, distinct territorial borders, and residential dwellings in the settlement blocks.

The findings, first, when matched between the principle of Tri Hita Kharana and the land use in Cakranegara city, show that Cakranegara city has the spatial hierarchical principle of Tri Hita Kharana. There are three kinds of worship sites as the empirical evidence for this. They are the temples of Mayura, Meru, and Dalem as Parahyangan, the territory of Cakranegara city as the body (Palemahan), and the population of Cakranegara city as Pawongan. Second, when matching the principle of Tri Angga, Tri Mandala, and Tri Loka with land use in Cakranegara city, it was found that Cakranegara city has spatial hierarchies of those three principals. There are two kinds of worship sites as the empirical evidence for this, they are the temples of Mayura and Meru to the east from the central crossroads representing the atmosphere (Shuahloka) and Utama, and in addition, Dalem temple and the graveyard to the west from the central crossroads which represent the hydrosphere (Bhurloka) and nista. Meanwhile, there are settlement blocks, representing the lithosphere (Bhuahloka) and madya. Thirdly, when matching the principle of Rwa Bhinneda and the land use in Cakranegara city, it is shown that Cakranegara city has a spatial orientation according to that of Rwa Bhinneda principal. There are two kinds of worship sites as the empirical evidence for this. They are the temples of Mayura and Meru located in the east representing the direction to Mount Rinjani and the sunrise, and the one temple (Dalam) in the westernmost part which represents its relation to Ampenan Sea and the sunset (Figure 5). 


\section{CONCLUSION}

Based on the discussion, it is concluded that the historical city of Cakranegara has main characteristics. First, the settlement blocks adopt the principle of Asta Dikpalaka. Second, the crossroads adopt the principle of Panca Brahma. Third, the structure of the city with a grid pattern is the adoption of: (1) the importance of a place to accommodate the social and ritual religious activities; (2) the settlement blocks to accommodate the immigranst to Bali Island in groups from their native region; and (3) the belief of niskala power at each crossroad. Fourth, the spatial orientation of Cakranegara city adopts the principle of Rwa Bhinneda, where the spatial hierarchy of Cakranegara city adopts the principle of Tri Hita Kharana, Tri Angga, Tri Mandala, and Tri Loka.

\section{REFFERENCE}

Agung, Anak Agung K. (1992). Kupu-kupu Kuning yang Terbang di Selat Lombok, Penerbit PT, Upada Sastra, Denpasar Bali.

Aminuddin, R.A.D. (1999). Konsep Kosmologi, Pusat Pengajian Islam dan Pembangunan Sosial Universiti Teknologi Malaysia, Skudai, Johor Bahru.

Atmaja, Ida Bagus O.P. (1999). Bali dan Masa Depannya, Tri Hita Karana, (Wayan Supartha Penyunting), PT, Bali Post, Denpasar Bali.

Atmaja, J. (2003). Perempatan Agung, Menguak Konsep Palemahan Ruang dan Waktu Masyarakat Bali, Penerbit Bali Media Adhikarsa, Denpasar Bali.

Banerjee, Tridib and Southworth, Michael (ed). (1990). Sense and City Design - Writings and Project of Kevin Lynch, The MIT Press, Massaachusetts, London and Cambridge.

Bell, Baum A. Fischer J. and Greene, T. (1990). Environmental Psychology, Holt, Rincart and Winston Inc.

Budihardjo, E. (1991). Architectural Conservation in Bali, Gadjah Mada University Press, Yogyakarta.

Cool, Capt. W. (1896). De Lombok Expeditie, Batavia, G. Kolt dan CO.

De Graaf, H.J. (1941). Lombok in de 17e, Eeuw, Djawa, 21, 6.

De Vaus (1991). Surveys in Social Research, Allen and Unwin.

Dharmayudha, I Made S. and Cantika, I Wayan K. (1999). Filsafat Adat Bali, Penerbit PT, Upada Sastra, Denpasar.

Djelenga, H. L. (2001). Sejarah Lombok dan Beberapa Bukti Peninggalannya, Mataram Press, Mataram.

Eiseman, JR. Fred B. (2005). Bali Sekala and Niskala, Volume I: Essay on Religion, Ritual and Art, Published by Periplus Editions (HK) Ltd, Singapore.

Festinger, L. and Katz, D. (1953). Research Methods in the Behavioural Sciences, Holt, Rinchart and Winston.

Funo, S. (1995). Cakranegara, A Unique Hindu City in Lombok (Indonesia) The Grid in the Tradition of Asian City Planning, Makalah yang disampaikan dalam Seminar Arsitektur Nusantara, Keajekan dan Perubahan, World Trade Centre, Surabaya.

Gelebet, I Nyoman (1986). Arsitektur Tradisional Daerah Bali, Departemen Pendidikan dan Kebudayaan, Denpasar Bali.

Geriya, S.S. (2004). Upacara Bayi dalam Kandungan, Penerbit Paramita, Surabaya.

Gorda, I Gusti N. (1996). Etika Hindu dan Perilaku Organisasi, Widya Kriya Gematama, Denpasar Bali.

Handinoto (2000). "Sistem Jalan di Cakranegara dan Purbolinggo, Sebuah Perbandingan", Jurnal Dimensi, Petra Press, Surabaya.

Hermanislamet, B. (1999). Tata Ruang Kota Majapahit, Analisis Keruangan Bekas Pusat Kerajaan Hindu Jawa Abad XIV di Trowulan Jawa Timur, Unpublished Ph.D Dissertation, Universitas Gadjah Mada, Yogyakarta.

Kaler, I Gusti K. (1994). Butir-Butir Tercecer tentang Adat Bali, Penerbit CV, Kayumas Agung, Denpasar Bali.

Levi-Strauss (1969). Totemism, Diterjemahkan dari Bahasa Perancis oleh R. Needham, Penguin Books, Middlesex. 
Mantra, Ida Bagus (1988). Masalah Sosial Budaya Khususnya Pembangunan di Bali dalam Rangka Menyongsong Era Tinggal Landas, Pusat Penelitian Universitas Udayana, Denpasar Bali.

Monografi (1985). Monografi Daerah Bali, Proyek Pemerintah Daerah Tingkat I Propinsi Bali, Denpasar Bali.

Mulyadi, L. (2008). Karektor dan Konsep Susun Atur Ruang Bandar Bersejarah Cakranegara Indonesia, Unpublished Ph.D Dissertation, Universiti Teknologi Malaysia, Skudai, Johor Bahru.

Munandar, A.H. (2005). Istana Dewa Pulau Dewata. Makna Puri Bali Abad Ke 14-19, Penerbit Komunitas Bambu, Jakarta.

Parimin, A.P. (1986). Fundamental Study on Spatial Formation of Island Village: Environmental Hirarchy of Sacred-profane Concept in Bali, Unpublished Ph.D Dissertation, University of Osaka, Japan.

Parisada Hindu Dharma (1995). Upadeca Tentang Ajaran-Ajaran Agama Hindu, Penerbit PT, Upada Sastra, Denpasar Bali.

Patra, Made S. (1992). Hubungan Seni Bangunan dengan Hiasan dalam Rumah Tinggal Adati Bali, Balai Pustaka, Jakarta.

Pidarta, Made (2000). Hindu Untuk Masyarakat Umum, Penerbit Paramita, Surabaya.

Puja, G. (1985). Suatu Pengantar dalam Weda, TP, Jakarta.

Rahardjo, M.P. (1989). Meaning in Balines Traditional Architecture, Unpublished Magister Thesis, University of Kansas, Lawrence.

Salim, M. (1992). Aspect of Urban Design With Special Reference to Image and Identity in Built Form-Case Study of Kuala Lumpur, Unpublished Ph.D Dissertation.

Samadhi, T.N. (2001). "The Urban Design of a Balinese Town, Placemaking Issues in The Balinese Urban Setting”, Journal Habitat International, 25/4:559-575.

Samadhi, T.N. (2004). Perilaku dan Pola Ruang, Penerbit Lembaga Penelitian dan Pengabdian Masyarakat Intitut Teknologi Nasional, Malang Jawa Timur.

Shuhana S. (1997). Identity of Place - A Case Study of Kuantan Town Centre, Unpublished Ph.D Dissertation, University of Nottingham Institute of Urban Planning.

Shuhana S. and Ahmad Bashri S. (1992). Typology of Urban Form of Old Town Centres in Malaysia, Unpublished Research Report, Universiti Teknologi Malaysia, Skudai, Johor Bahru.

Shuhana S. and Ahmad Bashri S. (1999). Public Perception of Urban Spaces - A Case Study Centre of Bandaraya Johor Bahru, Unpublished Research Report, Jabatan Seni Bina, Fakulti Alam Bina, Universiti Teknologi Malaysia, Skudai, Johor Bahru.

Shuhana S. and Ahmad Bashri S. (2002). Developing A Guideline for Designing Urban Intervention in Places of Historical and Cultural Significance in Malaysia, Unpublished Research Report, Jabatan Seni Bina, Fakulti Alam Bina, Universiti Teknologi Malaysia, Skudai, Johor Bahru.

Soeka, I Gde (2004). Tri Murthi Tattwa, Penerbit CV, Kayumas Agung, Denpasar Bali.

Soewarno, N. (1990). Transmigration Built Form and Ethnicity, Unpublished Ph.D Dissertation, University of Newcastle Upon Tyle.

Spreiregen, Paul D. (1965). Urban Design, The Architecture of Town and Cities, McGrawHill, New York.

Sudharta, T.R. and Atmaja, Ida Bagus O.P. (2005). Upadesa, Tentang Ajaran-Ajaran Agama Hindu, Penerbit Paramita, Surabaya.

Sugiyono (2009). Metode Penelitian Kualitatif Kuantitatif dan R\&D, Penerbit CV, Alfabeta, Bandung.

Sularto, R. (1987). Arsitektur Tradisional Bali dan Permasalahannya, BIC, Denpasar Bali.

Suparman (2003). Tri Hita Kharana sebagai Landasan Hidup Masyarakat Bali, (Jiwa Atmaja penyunting), Penerbit CV, Bali Media Adhikarsa, Denpasar Bali.

Suwena, I Wayan (2003). Makna Orientasi Arah di Bali dalam Perempatan Agung, Atmaja (editor), Penerbit CV, Bali Media Adhikarsa, Denpasar Bali.

Wacana, H.L. (1988). Sejarah Daerah Nusa Tenggara Barat, Depdikbud, NTB, Mataram.

Walker, R. (1985). Applied Qualitative Research, Gower Publishing Co, Ltd, Aldershot.

Widana, I Gusti K. (2002). Mengenal Budaya Hindu di Bali, Penerbit PT, Pustaka Bali Post, Denpasar Bali.

Wiryomartono, A.B.P. (1995). Seni Bangunan dan Seni Binakota di Indonesia, Kajian Mengenai Konsep, Struktur dan Elemen-Elemen Fisik Kota sejak Peradaban HinduBudha, Islam hingga Sekarang, Penerbit PT, Gramedia Pustaka Utama, Jakarta.

Zakaria, Fath (1998). Mozaik Budaya Orang Mataram, Yayasan Sumurmas Al Hamdy, NTB, Mataram. 